\title{
Effect of Air Heat Pump Cooling System as a Greener Energy Source on the Air Quality, Housing Environment and Growth Performance in Pig House
}

\author{
Dhanushka Rathnayake ${ }^{1,+} \oplus$, Hong-Seok Mun ${ }^{1,2,+}$, Muhammad Ammar Dilawar ${ }^{1,3} \mathbb{C}^{1}$, Il-Byung Chung ${ }^{1}$, \\ Kwang-Woo Park ${ }^{4}$, Sang-Ro Lee ${ }^{4}$ and Chul-Ju Yang ${ }^{1,3, *}$ \\ 1 Animal Nutrition and Feed Science Laboratory, Department of Animal Science and Technology, \\ Sunchon National University, Suncheon 57922, Korea; dhanus871@gmail.com (D.R.); \\ mhs88828@nate.com (H.-S.M.); ammar_dilawar@yahoo.com (M.A.D.); ilbyungchung@daum.net (I.-B.C.) \\ 2 Department of Multimedia Engineering, Sunchon National University, Suncheon 57922, Korea \\ 3 Interdisciplinary Program in IT-Bio Convergence System (BK21 Plus), Sunchon National University, \\ 255, Jungang-ro, Suncheon 57922, Korea \\ 4 WP Co., Ltd., Suncheon 58023, Korea; pkw9872@naver.com (K.-W.P.); skylife37@naver.com (S.-R.L.) \\ * Correspondence: yangcj@sunchon.ac.kr; Tel.: +82-61-750-3235 \\ + Both authors have equal contributions to this work as co-first authors.
}

\section{check for}

updates

Citation: Rathnayake, D.; Mun, H.-S.; Dilawar, M.A.; Chung, I.-B.; Park,

K.-W.; Lee, S.-R.; Yang, C.-J. Effect of Air Heat Pump Cooling System as a Greener Energy Source on the Air Quality, Housing Environment and Growth Performance in Pig House. Atmosphere 2021, 12, 1474. https:// doi.org/10.3390/atmos12111474

Academic Editors: Sheng-Lun Lin and Xin Wang

Received: 20 October 2021

Accepted: 5 November 2021

Published: 8 November 2021

Publisher's Note: MDPI stays neutral with regard to jurisdictional claims in published maps and institutional affiliations.

Copyright: (c) 2021 by the authors. Licensee MDPI, Basel, Switzerland. This article is an open access article distributed under the terms and conditions of the Creative Commons Attribution (CC BY) license (https:// creativecommons.org/licenses/by/ $4.0 /)$.
Abstract: The present study examined the cooling effects of an air heat pump (AHP) system. An AHP system was installed in a pig house to compare the effects with a traditional cooling system on the growth performance, noxious gas emission, housing environment and consumption of electricity. During the 19-week experimental trial, the internal temperature in the AHP cooling system-connected pig house was significantly decreased $(p<0.05)$ than the conventional house. Similarly, the temperature-humidity index (THI) was significantly reduced $(p<0.05)$ in the growing and late finishing period. The carbon dioxide $\left(\mathrm{CO}_{2}\right)$ and electricity consumption were also reduced significantly in the AHP cooling system relative to the control. The concentration of ammonia $\left(\mathrm{NH}_{3}\right)$ during the weaning and finishing phase and the concentration of hydrogen sulfide $\left(\mathrm{H}_{2} \mathrm{~S}\right)$ during all periods were lower in the AHP-installed pig house $(p<0.05)$. From $0-19$ weeks, there was no significant difference was observed $(p>0.05)$ in terms of the growth performance of pigs in both houses. These results show that the AHP cooling system can be implemented as an environmentally friendly renewable energy source in swine farms for sustainable pig production and better air quality without adversely affecting productivity parameters.

Keywords: renewable energy source; air quality; air heat pump; noxious gas emission; electricity consumption; pig house

\section{Introduction}

Effective and sustainable energy sources for the livestock and agriculture sector are currently needed because of the limited global fossil fuel availability. The fast-growing economic sector has increased the demand for various renewable resources, such as wind, biogas, and photovoltaic energy against the decreasing fossil energy resources [1]. In addition, scientists have found that $\mathrm{CO}_{2}$ emissions to the atmosphere have increased by $31 \%$ since the 17 th century, with an annual increment of $1.5 \mathrm{ppm}$ [2]. According to Oliver et al. [3], fossil-fuel combustion is responsible for $90 \%$ of $\mathrm{CO}_{2}$ emissions, which is as harmful as deforestation and excessive arable land operations. Thus, implementing renewable energy sources will facilitate sustainable energy consumption, improved energy production, and environmental protection.

It is essential to provide optimal temperature levels in swine houses to ensure their growth performance because they have an underdeveloped thermoregulation process [4,5]. Additionally, the pig industry's most recent challenges are enhancing the animals' growth 
rate, reducing energy cost and noxious gas emissions, and improving animal and workers' welfare. A significant amount of economic cost has been allocated to the heating or cooling system of pig houses, particularly the areas associated with harsh weather conditions. The Minnesota center for farm financial management reported that approximately $5 \%$ of the production cost is utilized for electrical and fuel usage [6]. Moreover, elevated $\mathrm{NH}_{3}$ and $\mathrm{H}_{2} \mathrm{~S}$ gas emissions adversely affect the animals' welfare, optimal growth performance, workers in the buildings, and neighbors. Similarly, particulate matter $\left(\mathrm{PM}_{2.5}\right)$ produced at farms can penetrate the respiratory organs quickly because of their small particle size and cause respiratory diseases. Furthermore, the main sources of volatile organic compounds (VOCs) emission are feed, technological devices, bedding and as well as animal. The VOCs produced due to the decomposition of animal organic substances are noxious to people and the environment or even carcinogenic [7]. Therefore, it is essential to find solutions for those problems associated with the pig housing environment and high energy consumption.

Geologically, South Korea has abundant renewable energy resource capacity. The Korean government is taking steps to increase the use of new and renewable energy from $2.1 \%$ in 2004 to $11 \%$ in 2030 [8]. Thus, examining possible renewable energy source utilization is worthwhile. Air source heat pumps (AHP) are gaining popularity these days because the ambient air is widely and freely available [9]. Air source heat pumps (AHP) and connected components can provide energy savings and storage, effectively use low-grade energy and conserve high-grade energy. In addition to energy savings., it has the potential to minimize greenhouse gas emissions [10]. By carefully reviewing all the cooling mechanism (cooling pads with fans, fogging techniques, industrial fans) in the pig farm, it is observed that the drawbacks of these methods are increased air relative humidity, formation of dust particles, and wastage of non-renewable resources [11]. Therefore, the AHP heating and cooling system can be utilized as a substitute energy source to conventional electric systems because it is an eco-friendly and sustainable source [12]. Several authors [12,13] have examined the experimental and theoretical application and effectiveness of air heat pumps. However, according to the best of our knowledge, there is no study available on the cooling effects of air heat pump systems on the housing environment and energy efficiency in pig farms. Therefore, the purpose of this article is to discuss the effects of an AHP cooling system on swine growth performance, housing conditions $\left(\mathrm{H}_{2} \mathrm{~S}, \mathrm{NH}_{3}, \mathrm{PM}_{2.5}\right.$, and formaldehyde), electricity consumption and economic efficiency.

\section{Materials and Methods}

\subsection{Ethics and Animal Care}

The study procedures, management, and care of pigs in the experiment followed good animal husbandry practices. The methodology was reviewed and approved by the IACUC (Institutional Animal Care \& Use Committee) at Sunchon National University (SCNU IACUC-2020-09).

\subsection{Experimental Period and House}

The experiment was performed at the experimental farm at Sunchon National University, Republic of Korea. The effects of the AHP cooling system in a swine house were evaluated for 19 weeks (five weeks for weaning piglets; four weeks for growing pigs, and five weeks for early finishing and late-finishing pigs) in summer from 29 May 2020 to 9 October 2020.

The experimental house consisted of two separate east-facing rooms $(3 \mathrm{~m} \times 8 \mathrm{~m})$ was subdivided into 10 pens with one pig in each pen. The room positioned in the south area of the pig house was equipped with a conventional cooling system (ventilation fans) and considered as control. The other rooms facing the north side area of the pig house were connected to the air pump cooling system (Figure 1). The outer side walls were made of plastered bricks, and the floor was made of a plastic slat to remove the slurry easily. 


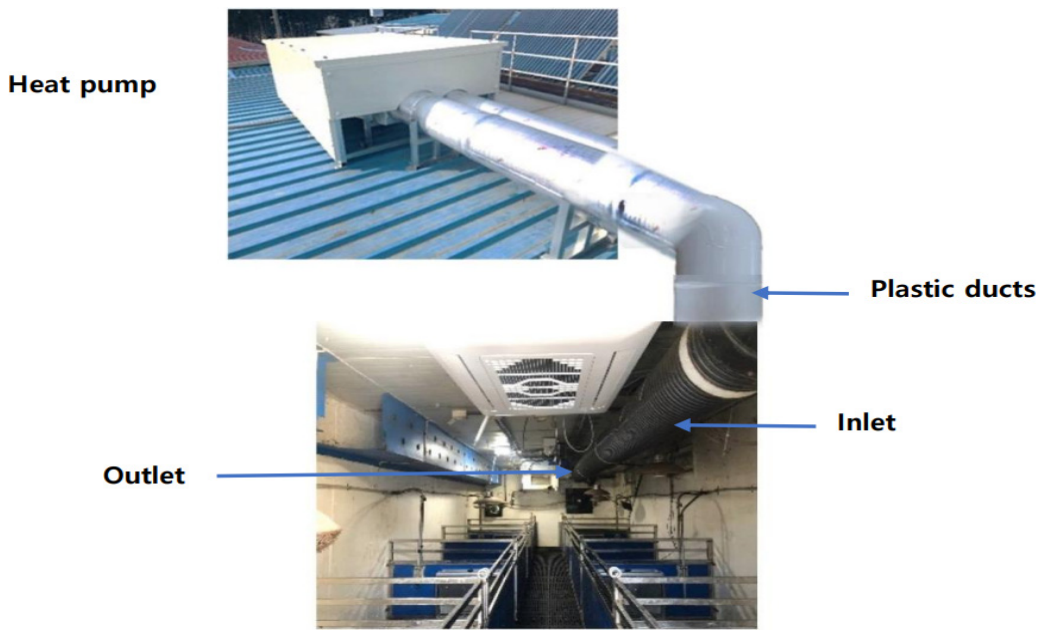

Figure 1. The schematic design of the air heat pump (AHP) cooling system [13].

The outdoor unit absorbed the heated atmospheric air and transported it to the outdoor unit of the air-conditioner. The cooled air generated from the AHP system was moved to the inside of the pig house through an internal plastic tube network with tiny pores. Ultimately, the heated liquid-vapor coolant mixture re-entered the outdoor unit to be cooled again. The inside temperature and ventilation rate were maintained automatically in the AHP cooling system-connected pig house. The ventilation rate was regulated at $75 \mathrm{CFM}$ / unit for finishing pigs, $35 \mathrm{CFM}$ / unit for growing pigs and $25 \mathrm{CFM}$ for weaning pigs. The initial setting temperatures were similar in both swine houses according to the specific growth phases to compare fluctuations in temperature and other parameters between experimental pig houses. Moreover, all experimental animals were fed ad libitum using a commercial basal diet [14] and provided clean and fresh drinking water.

The daily electricity consumption was evaluated by installing individual electric meters in both houses (LSis, LD 1210Ra-040, Seoul, Korea). Moreover, subsequent $\mathrm{CO}_{2}$ emissions from both houses were calculated in $\mathrm{kgCO}_{2} \mathrm{e}\left(1 \mathrm{kWh}=0.483 \mathrm{~kg} \mathrm{CO}_{2}\right.$ equivalent) [15].

\subsection{Air Heat Pump (AHP) System}

The AHP system was installed and connected (BW1450M9S, LG Electronics Inc., Seoul, Korea) to the swine building at the experimental farm, as described by Jeong et al. [13]. The modified AHP system consisted of an inhale chamber, air inlet, air heat pump compressor, air-circulating pipes, and discharge chamber (Figure 2). The minimum and maximum cooling capacity of the system is $5.4 \mathrm{~kW}$ and $16.7 \mathrm{~kW}$, respectively, and cooling power consumption is $1.1 \mathrm{~kW}$ and $5.8 \mathrm{~kW}$, respectively.

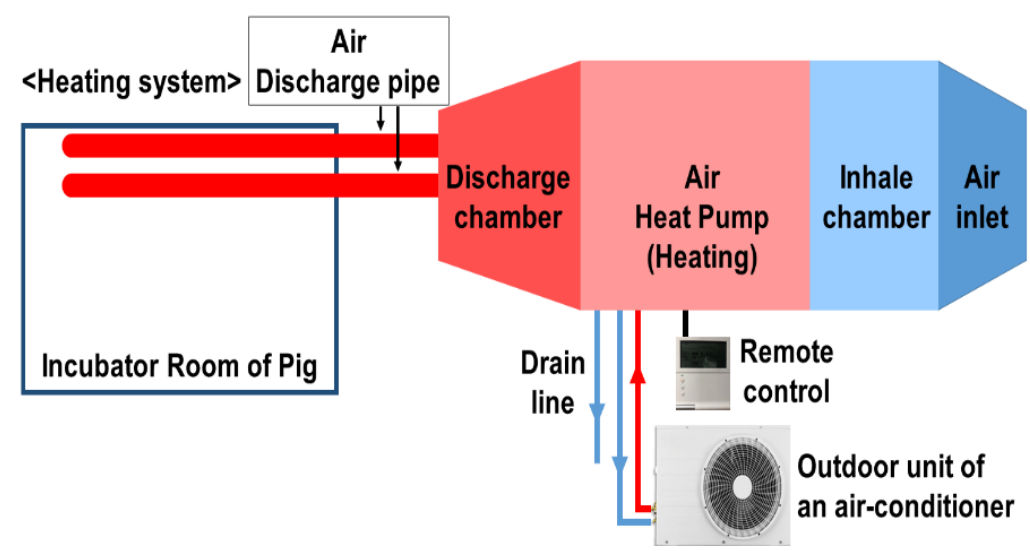

Figure 2. The outline of the air heat pump (AHP) cooling system [13]. 


\subsection{Measurement and Analysis}

The body weight gain (BWG), feed intake (FI), and feed conversion ratio (FCR) were evaluated in all growth phases of the study. The starting and finishing weights were divided by the four experimental periods to obtain the weight gain. Furthermore, the feed weight differences were evaluated every week before the weight gain measurements. The FCR was calculated as the ratio of feed intake by the average daily gain. The temperature and humidity of pig houses were measured using an SMT-75, 8-bit-smart sensor (Seoul semiconductor, Seoul, South Korea) with a range of $-20^{\circ} \mathrm{C}$ to $-80^{\circ} \mathrm{C}$.

The coefficient of performance (COP) of the AHP system was calculated by the method described by Jeong et al. [13]. The temperature-humidity index (THI) was calculated from relative humidity and temperature as an indicator of heat stress index using the following equation [16].

$$
\mathrm{THI}=0.8 \mathrm{~T}+(\mathrm{RH} / 100) \times(\mathrm{T}-14.3)+46.4
$$

\subsection{Housing Conditions Analysis}

The concentration of $\mathrm{NH}_{3}$ within the pig house was measured using a City Technology, $\mathrm{NH}_{3}$ sensoric-3E $100 \mathrm{SE}$ (City Technology, Bonn, Germany), and the concentration of $\mathrm{H}_{2} \mathrm{~S}$ was measured using an $\mathrm{H}_{2} \mathrm{~S}-\mathrm{B} 4$ sensor (Alphasense Ltd., Great Notley, UK). Both gas sensors were established inside the two pig houses at the height of $1.9 \mathrm{~m}$ with a range of 0-50 ppm.

A smart air quality sensor (AR830A-Smart Sensor, Dongguan, China) with a formaldehyde range of $0-5 \mathrm{ppm}$, total volatile organic compounds (TVOCs) with a range of $0-5 \mathrm{ppm}$ and a fine particulate matter $\left(\mathrm{PM}_{2.5}\right)$ range of $0-150 \mu \mathrm{g} / \mathrm{m}^{3}$ was used to calculate the formaldehyde level, TVOCs and $\mathrm{PM}_{2.5}$.

\subsection{Statistics}

The Statistical Analysis System (SAS, 2011, Version 9.3, SAS Institute, Cary, NC, USA) was used to analyze the data gathered. The Duncan's Multiple Range Test was used to calculate the growth performances, which included feed intake, final body weight, weight gain, and gain: feed ratio. A two-way $t$-test was used to assess noxious gas emissions $\left(\mathrm{NH}_{3}\right.$ and $\mathrm{H}_{2} \mathrm{~S}$ ), formaldehyde levels and $\mathrm{PM}_{2.5}$. The mean and standard error of the mean is used to describe the data (SEM). A $p<0.05$ value was considered significant.

\section{Results}

\subsection{Effects of the AHP Cooling System on the Growth Performance of Swine}

Table 1 lists the growth performance of swine during weaning, growing, earlyfinishing, and late-finishing phases. There was no significant difference $(p>0.05)$ observed in any growth parameter during the weaning period ( $0-5$ weeks). Moreover, the FCR of the control and AHP cooling system connected pig houses did not differ significantly $(p>0.05)$. However, a significant difference $(p<0.05)$ was observed in the FI during the growing and late finishing period. On average, no profound significant difference $(p>0.05)$ was found in the growth performance parameters during the $0-19$ weeks' experimental period.

Table 1. Effect of the AHP cooling system on the growth performance parameters of pigs.

\begin{tabular}{|c|c|c|c|c|}
\hline Parameters & Control & AHP & SEM & $p$-Value \\
\hline \multicolumn{5}{|c|}{ Weaning Period ( $0-5$ weeks) } \\
\hline Initial body weight $(\mathrm{kg})$ & 6.18 & 6.16 & 0.37 & 0.9712 \\
\hline Final body weight (kg) & 23.74 & 25.13 & 1.03 & 0.3902 \\
\hline Weight gain $(\mathrm{kg})$ & 17.56 & 18.97 & 0.93 & 0.3311 \\
\hline Feed intake (kg) & 26.6 & 29.18 & 1.19 & 0.1708 \\
\hline FCR & 1.52 & 1.55 & 0.06 & 0.6803 \\
\hline
\end{tabular}


Table 1. Cont.

\begin{tabular}{|c|c|c|c|c|}
\hline Parameters & Control & AHP & SEM & $p$-Value \\
\hline \multicolumn{5}{|c|}{ Growing period (6-9 weeks) } \\
\hline Initial body weight (kg) & 23.74 & 25.13 & 1.03 & 0.3871 \\
\hline Final body weight (kg) & 48.53 & 50.08 & 2.21 & 0.6432 \\
\hline Weight gain $(\mathrm{kg})$ & 24.79 & 24.95 & 1.20 & 0.8921 \\
\hline Feed intake (kg) & $67.68^{\mathrm{a}}$ & $54.62^{\mathrm{b}}$ & 2.81 & 0.0085 \\
\hline FCR & 2.78 & 2.94 & 0.15 & 0.4781 \\
\hline \multicolumn{5}{|c|}{ Early-finishing period (10-14 weeks) } \\
\hline Initial body weight (kg) & 48.53 & 50.08 & 2.21 & 0.6422 \\
\hline Final body weight (kg) & 75.61 & 78.80 & 2.90 & 0.4793 \\
\hline Weight gain $(\mathrm{kg})$ & 27.09 & 28.72 & 1.30 & 0.0931 \\
\hline Feed intake (kg) & 81.29 & 86.26 & 3.02 & 0.2611 \\
\hline FCR & 3.84 & 3.50 & 0.16 & 0.1721 \\
\hline \multicolumn{5}{|c|}{ Late-finishing (5-19 weeks) } \\
\hline Initial body weight (kg) & 75.61 & 78.80 & 2.90 & 0.4791 \\
\hline Final body weight (kg) & 108.47 & 113.38 & 3.64 & 0.3692 \\
\hline Weight gain $(\mathrm{kg})$ & 32.86 & 34.58 & 0.65 & 0.4234 \\
\hline Feed intake (kg) & $101.16^{\mathrm{b}}$ & $113.24^{\mathrm{a}}$ & 3.91 & 0.0436 \\
\hline FCR & 4.04 & 4.33 & 0.17 & 0.2411 \\
\hline \multicolumn{5}{|c|}{ Average (0-19 weeks) } \\
\hline Initial body weight (kg) & 6.18 & 6.16 & 0.37 & 0.9701 \\
\hline Final body weight (kg) & 108.47 & 113.38 & 3.65 & 0.3693 \\
\hline Weight gain $(\mathrm{kg})$ & 102.29 & 107.22 & 3.55 & 0.3565 \\
\hline Feed intake (kg) & 276.74 & 283.30 & 8.58 & 0.5991 \\
\hline FCR & 2.55 & 2.64 & 0.05 & 0.2876 \\
\hline
\end{tabular}

$\overline{\mathrm{a}, \mathrm{b}}$ Mean values with different superscripts within the same row are statistically significantly $(p<0.05)$.

3.2. Effects of the AHP Cooling System on the Internal Housing Temperature $\left({ }^{\circ} \mathrm{C}\right)$, Temperature Humidity Index (THI), and Coefficient of Performance (COP)

The temperature inside the AHP connected pig house during each period was significantly lowered $(p<0.05)$ than the outside and control pig house temperature (Table 2). On average, the temperature decreased by $22.25 \%$ in the AHP system compared to the outside temperature and $12 \%$ relative to the control house. Similarly, the THI of the AHP installed pig house was significantly reduced as compared with the control during the growing and finishing phase (Figure 3). The minimum and maximum COP calculated in this study was 3.95 for the finishing period and 4.10 for the weaning period (Table 2).

Table 2. Effect of the AHP cooling system on the inside temperature $\left({ }^{\circ} \mathrm{C}\right)$ of the pig house and coefficient of performance (COP).

\begin{tabular}{ccccccc}
\hline Growth Phase & Outside & Control & AHP & SEM & $\boldsymbol{p}$-Value & Average COP \\
\hline Weaning & 28.70 & $25.85^{\mathrm{a}}$ & $25.01^{\mathrm{b}}$ & 0.21 & 0.0055 & 4.10 \\
Growing & 27.31 & $24.31^{\mathrm{a}}$ & $21.12^{\mathrm{b}}$ & 0.21 & $<0.0001$ & 3.90 \\
Early-finishing & 31.12 & $27.76^{\mathrm{a}}$ & $23.44^{\mathrm{b}}$ & 0.15 & $<0.0001$ & 3.98 \\
Late-finishing & 26.49 & $22.15^{\mathrm{a}}$ & $18.60^{\mathrm{b}}$ & 0.17 & $<0.0001$ & 3.95 \\
Average & 28.40 & $25.03^{\mathrm{a}}$ & $22.02^{\mathrm{b}}$ & 0.22 & $<0.0001$ & 3.89 \\
\hline
\end{tabular}

$\overline{\mathrm{a}, \mathrm{b}}$ Mean values with different superscripts within the same row are statistically significant $(p<0.05)$. 


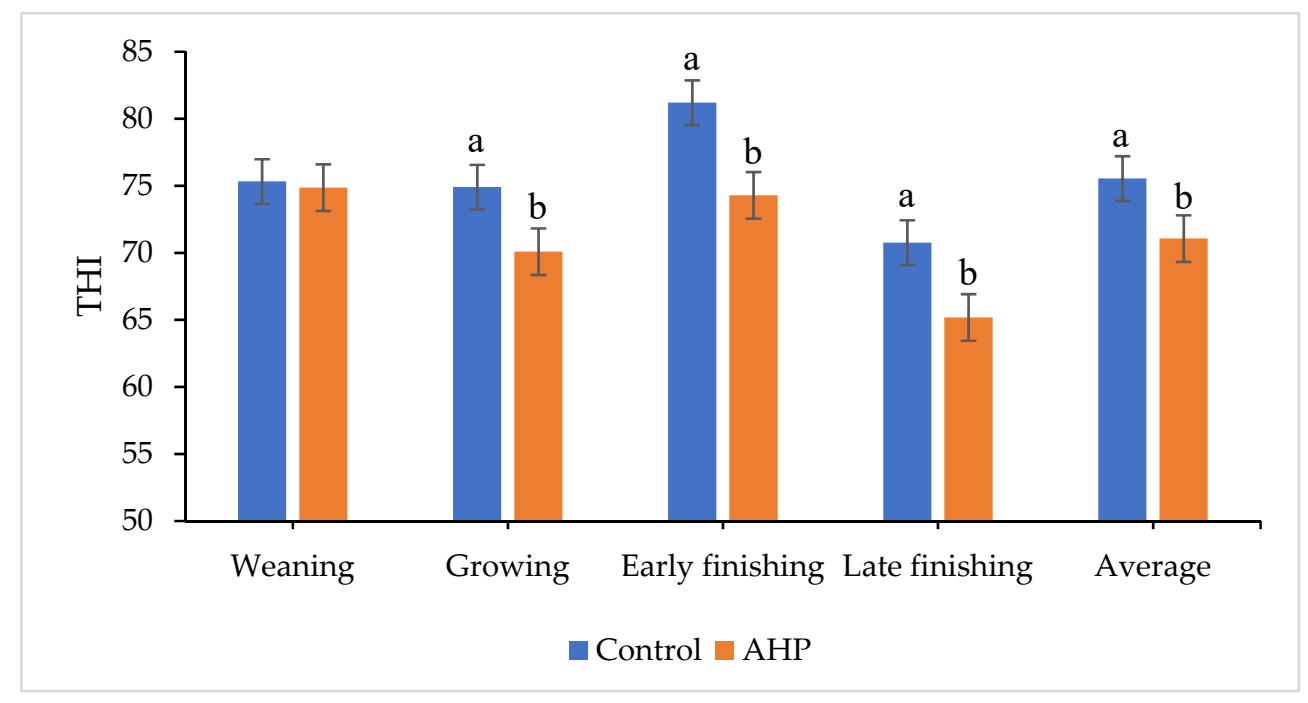

Figure 3. Effect of the AHP cooling system on the temperature-humidity index (THI). Data are presented as mean \pm SEM. ${ }^{\text {a,b }}$ Values with different superscripts within the same bars differ significantly $(p<0.05)$.

3.3. Effects of the AHP Cooling System on the $\mathrm{NH}_{3}(p p m)$ and $\mathrm{H}_{2} \mathrm{~S}(\mathrm{ppm})$ Concentration inside the Swine House

Table 3 shows the $\mathrm{NH}_{3}$ concentration during the 19-week experimental period as affected by the AHP cooling system. The data shows that during the weaning and early finishing phases, the $\mathrm{NH}_{3}$ emissions decreased significantly $(p<0.05)$ in the AHP cooling system-connected pig house than the conventional cooling system. Conversely, the $\mathrm{H}_{2} \mathrm{~S}$ emissions were reduced significantly $(p<0.05)$ in the AHP cooling system during the weaning, growing, and finishing phases. However, $\mathrm{H}_{2} \mathrm{~S}$ emissions in the AHP-connected pig house were unaffected $(p>0.05)$. On average, the $\mathrm{H}_{2} \mathrm{~S}$ emissions decreased significantly in the AHP-connected pig house $(p<0.05)$ during the entire experiment period $(0-19$ weeks). The TVOC concentration was not affected $(p<0.05)$ by the AHP except for the growing phase (Table 3).

Table 3. Effects of the AHP cooling system on $\mathrm{NH}_{3}$ (ppm) and $\mathrm{H}_{2} \mathrm{~S}$ (ppm) concentrations in the pig house.

\begin{tabular}{|c|c|c|c|c|}
\hline Growth Phase & Control & AHP & SEM & $p$-value \\
\hline \multicolumn{5}{|c|}{ Ammonia $\left(\mathrm{NH}_{3} \mathrm{ppm}\right)$} \\
\hline Weaning & $2.54^{\mathrm{a}}$ & $2.25^{b}$ & 0.09 & 0.0190 \\
\hline Growing & 1.50 & 1.34 & 0.06 & 0.0710 \\
\hline Early-finishing & $1.46^{\mathrm{a}}$ & $1.18^{\mathrm{b}}$ & 0.09 & 0.0470 \\
\hline Late-finishing & $1.27^{\mathrm{b}}$ & $1.69^{\mathrm{a}}$ & 0.06 & 0.0001 \\
\hline Average & 1.71 & 1.63 & 0.05 & 0.3500 \\
\hline \multicolumn{5}{|c|}{ Hydrogen sulfide $\left(\mathrm{H}_{2} \mathrm{~S}\right.$ ppm) } \\
\hline Weaning & $0.01^{\mathrm{a}}$ & $0.00^{\mathrm{b}}$ & 0.02 & 0.0002 \\
\hline Growing & $0.01^{\mathrm{a}}$ & $0.00^{b}$ & 0.01 & 0.0318 \\
\hline Early-finishing & 0.01 & 0.01 & 0.01 & 0.4147 \\
\hline Late-finishing & $0.02^{\mathrm{a}}$ & $0.00^{\mathrm{b}}$ & 0.01 & 0.0318 \\
\hline Average & $0.01^{\mathrm{a}}$ & $0.00^{\mathrm{b}}$ & 0.02 & 0.0201 \\
\hline \multicolumn{5}{|c|}{ Total volatile organic compounds (TVOC ppm) } \\
\hline Weaning & 0.14 & 0.12 & 0.11 & 0.0170 \\
\hline Growing & $0.18^{a}$ & $0.13^{b}$ & 0.17 & 0.0047 \\
\hline Early-finishing & 0.13 & 0.12 & 0.08 & 0.2500 \\
\hline Late-finishing & 0.14 & 0.11 & 0.04 & 0.1610 \\
\hline Average & 0.15 & 0.12 & 0.10 & 0.1781 \\
\hline
\end{tabular}

$\overline{\mathrm{a}, \mathrm{b}}$ Mean values with different superscripts within the same row are statistically significant $(p<0.05)$. 
3.4. Effects of the AHP Cooling System on Total Volatile Organic Compounds, Formaldehyde, and Particulate Matter inside the Swine House

Figure 4 presents the effects of the AHP cooling system on the formaldehyde (ppm) concentration inside the pig house during the different growth phases. The formaldehyde concentration in the AHP cooling system connected pig house reduced significantly $(p<0.05)$ in the weaning and late finishing periods. Additionally, no significant difference was observed in both treatments during the early finishing and growing periods $(p>0.05)$. The $\mathrm{PM}_{2.5}$ concentration was comparable $(p>0.05)$ in both treatments during all growth phases (Figure 5). Although there was no significant difference, it was observed that numerical levels of the $\mathrm{PM}_{2.5}$ reduced in the AHP-connected pig house than in the control treatment.

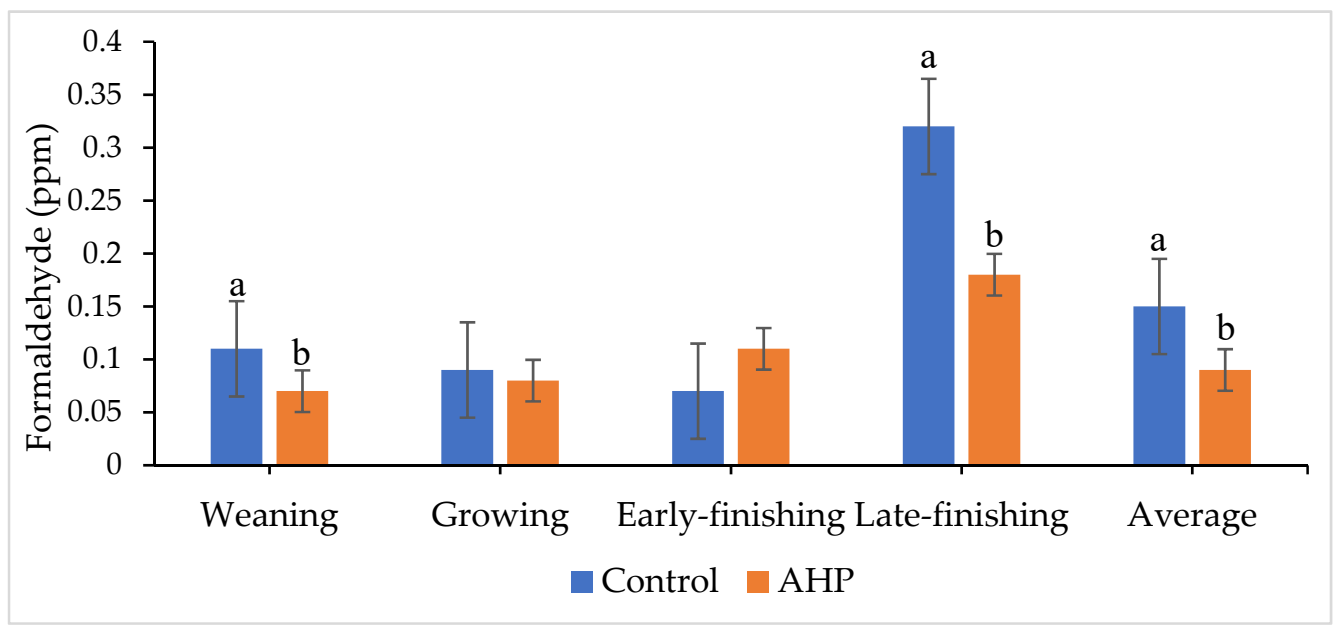

Figure 4. Effect of the AHP cooling system on the formaldehyde (ppm) concentration in the pig house. Data are presented as mean \pm SEM. ${ }^{a, b}$ Values with different superscripts within the same bars differ significantly $(p<0.05)$.

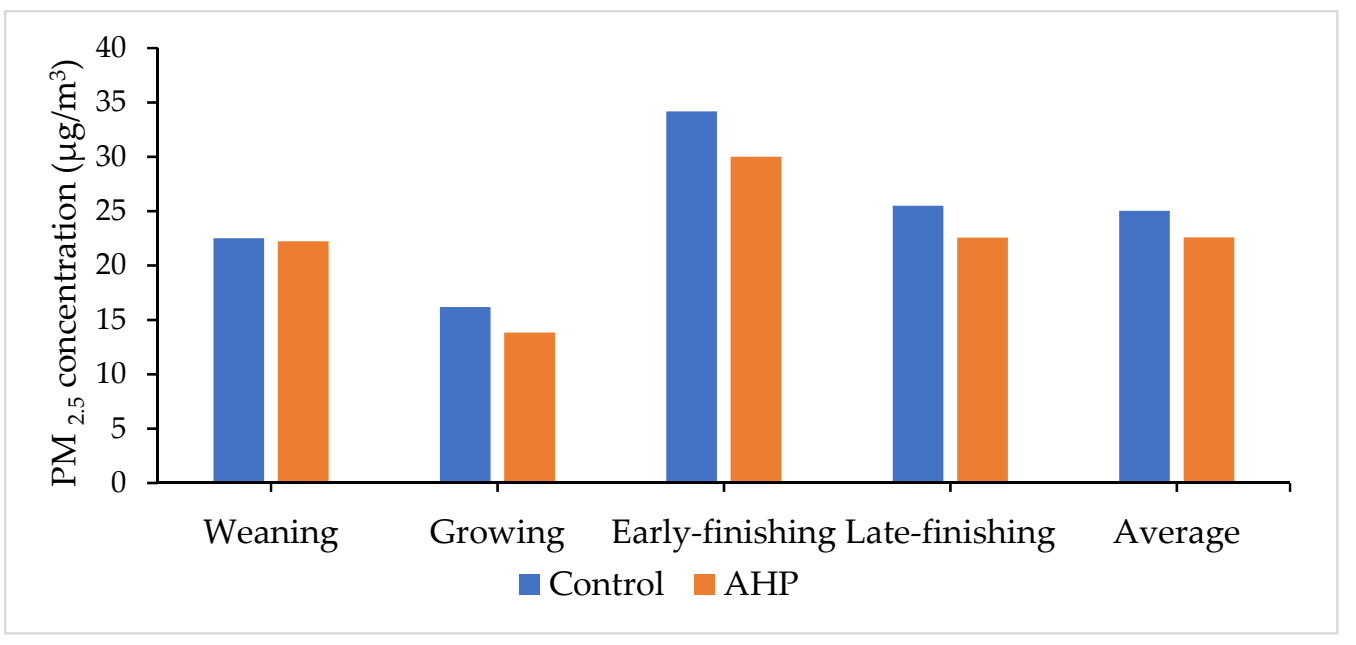

Figure 5. Effect of the AHP cooling system on the fine particulate matter $\left(\mu \mathrm{g} / \mathrm{m}^{3}\right)$ concentration in the pig house. Data are presented as mean \pm SEM.

\subsection{Effects of AHP Cooling System on the Energy Utilization and $\mathrm{CO}_{2}$ Emissions}

The data show that regardless of the growth phases, the pig house's energy consumption and $\mathrm{CO}_{2}$ emission connected with the AHP cooling system was reduced than the control (Table 4). On average, the energy consumption and $\mathrm{CO}_{2}$ emission were decreased by $12 \%$ in the AHP-connected pig house compared to the control. 
Table 4. Effects of the AHP cooling system on the energy utilization $(\mathrm{kWh})$ and $\mathrm{CO}_{2}$ emissions $(\mathrm{kg})$ in the pig house.

\begin{tabular}{|c|c|c|c|c|}
\hline \multirow[t]{2}{*}{$\begin{array}{l}\text { Growth Phase } \\
\text { (Weeks) }\end{array}$} & \multicolumn{2}{|c|}{$\begin{array}{c}\text { Energy Consumption } \\
(\mathbf{k W h})\end{array}$} & \multicolumn{2}{|c|}{$\begin{array}{c}\mathrm{CO}_{2} \text { Emission } \\
(\mathrm{kg})\end{array}$} \\
\hline & Control & AHP & Control & AHP \\
\hline \multicolumn{5}{|l|}{ Weaning } \\
\hline 1st week & 214.75 & 134.70 & 103.72 & 65.06 \\
\hline 2nd week & 117.10 & 69.90 & 56.56 & 33.76 \\
\hline 3rd week & 112.70 & 103.05 & 54.43 & 49.77 \\
\hline 4 th week & 62.30 & 92.60 & 30.09 & 44.73 \\
\hline 5th week & 61.65 & 80.48 & 29.78 & 38.87 \\
\hline Average & 113.70 & 96.15 & 54.92 & 46.44 \\
\hline \multicolumn{5}{|l|}{ Growing } \\
\hline 1st week & 46.60 & 41.25 & 22.51 & 19.92 \\
\hline 2nd week & 49.30 & 36.30 & 23.81 & 17.53 \\
\hline 3rd week & 60.05 & 57.25 & 29.00 & 27.65 \\
\hline 4th week & 63.60 & 71.20 & 30.72 & 34.39 \\
\hline Average & 54.89 & 51.50 & 26.51 & 24.87 \\
\hline \multicolumn{5}{|l|}{ Finishing } \\
\hline 1st week & 60.70 & 49.45 & 29.32 & 23.88 \\
\hline 2nd week & 61.30 & 45.60 & 29.61 & 22.02 \\
\hline 3rd week & 52.60 & 55.10 & 25.41 & 26.61 \\
\hline 4th week & 77.90 & 66.93 & 37.63 & 32.32 \\
\hline 5th week & 25.80 & 29.95 & 12.46 & 14.47 \\
\hline Average & 55.66 & 49.41 & 26.88 & 23.86 \\
\hline Total & 1066.35 & 933.75 & 515.05 & 451.00 \\
\hline
\end{tabular}

\section{Discussion}

Temperature and relative humidity are some of the most important parameters for the evaluation of pig house environments in mechanically ventilated and closed insulated buildings [17]. A slight fluctuation in these parameters can cause cold shock or heat stress in pigs. Pigs are more prone to heat stress in hot weather as they lack a proper panting system and a large deposit of subcutaneous fat under their skin [4]. In addition, Licharz et al. [18] reported that pig housing must have access to a comfortable indoor temperature to comply with animal welfare legislation. The inside temperature of the AHP connected pig house remained at a lower level during the entire experiment. These findings might be attributed to the equal distribution of the AHP cooling system inside the pig house due to its higher COP value and lower running period [13]. As the pigs get older, their optimum temperature decreases and they feel the detrimental effects of the heat stress at a relatively low temperature as compared with the weaning piglets. In the present study, the cooling mechanism of the AHP system significantly reduced the inside temperature up to $18^{\circ} \mathrm{C}$ during the late finishing period. These results are in agreement with the findings of Adebiyi et al. [16] that the optimum temperature for finishing pigs is below $20^{\circ} \mathrm{C}$. THI is used as a basis for the safety index to explain the categories of the heat stress due to high temperatures for livestock. It is reported by Myer and Bucklin [19] that only humidity itself is not harmful for swine production unless the high temperature is combined with high humidity. According to the National Atmospheric and Oceanic administration [20], $\mathrm{THI} \geq 84$ is considered an emergency, $\mathrm{THI} \leq 74$ is safe and $74<\mathrm{THI}<79$ is classified as an alert. In the present study, the temperature-humidity index for all phases of swine growth falls in the safety zone. This might be due to the better cooling performance of the AHP system in extremely hot and humid conditions.

In this study, no significant differences were observed in the average growth performance of swine from 0-19 weeks. Although not significant, the pigs raised in the AHP cooling system connected pig house exhibited a numerical increase in the final body weight 
and feed intake. Similarly, Jeong et al. [13] reported that the utilization of the AHP system in the pig house did not significantly influence the body weight gain and feed conversion ratio. The first study regarding the AHP system in a swine building was conducted by Riva et al. [21], who reported an improved feed intake, weight gain and feed conversion ratio in the AHP connected house as compared to the house connected to the LPG gas system. The reduced growth performance might be due to the elevated fume concentration in the LPG gas system-operating pig house. In short, using the AHP cooling system inside the pig house prevents the animals from heat stress without harming animal production and health, especially in modern genetic lines [11,22]. Hence, utilizing the AHP system-based energy distribution pattern is essential for housing schemes to keep sows and piglets at optimal temperatures [23].

The permissible level of $\mathrm{NH}_{3}$ recommended by the International Commission of Agricultural and Bio-Systems Engineering (CIGR) is $20 \mathrm{ppm}$ [24]. Generally, $\mathrm{NH}_{3}$ concentration in the swine farm range between 0 to $40 \mathrm{ppm}$, and $\mathrm{H}_{2} \mathrm{~S}$ concentration is usually less than 2 ppm [25]. The $\mathrm{NH}_{3}$ emissions in this experiment were significantly reduced in the AHP cooling system connected pig house. The lower noxious gas emission in the AHP cooling system might be due to the increased fresh air moving into the pig house. Another reason for the lower $\mathrm{NH}_{3}$ concentration is the absorption of ammonia by the condenser. Riva et al. [21] also observed a large amount of damp dust rich in ammonia nitrogen on the exchanger. The recent findings confirm with the previous reports that the level of $\mathrm{NH}_{3}$ emission may increase in intensive livestock houses due to the higher temperature fluctuations [26,27]. Similarly, the average effect of the AHP cooling system in $\mathrm{H}_{2} \mathrm{~S}$ emission was significantly reduced than the recommended threshold levels. Hence, implementing an AHP cooling system is a practical and sustainable step in the intensive swine industry. Another critical aspect of swine building is associated with the concentration of particulate matter. $\mathrm{PM}_{2.5}$ has become a critical public health concern in some countries, and its major cause is the burning of fossil fuels. In this study, $\mathrm{PM}_{2.5}\left(\mu \mathrm{g} / \mathrm{m}^{3}\right)$ was numerically lower in the AHP cooling system connected pig house relative to the conventional pig house. These findings are supported by Jeong et al. [13] that AHP can reduce $\mathrm{PM}_{2.5}$, as there is no emission from the AHP system due to the burning of fossil fuels. On the other hand, the levels of formaldehyde during weaning and late finishing growth stages of swine are significantly lower than in the conventional pig house. This could be ascribed to the AHP pig house's optimum air circulation. However, the relationship between formaldehyde levels, $\mathrm{PM}_{2.5}$ concentrations, and AHP system installation is unclear. As a result, further research in future is needed to determine the impact of $\mathrm{PM}_{2.5}$ and formaldehyde on the use of renewable energy sources.

Renewable energy sources are gaining popularity in the livestock sector because they can reduce electricity consumption and are environmentally friendly. Additionally, in the present study, the AHP system decreased the consumption of electricity and $\mathrm{CO}_{2}$ emission in the pig house as compared to the conventional cooling system. These results are in agreement with a study conducted by Rabczak et al. [28] that the AHP system inside the large-scale buildings reduced the release of $\mathrm{CO}_{2}$ into the atmosphere by $40 \%$. Similarly, in our previous study using the same AHP during the heating phase, the electricity consumption was decreased by $63 \%$ [13]. Furthermore, many studies $[9,29,30]$ have reported that energy consumption and greenhouse gas emissions were reduced by replacing an existing heating and cooling systems with heat pumps for animal farms and residential buildings. The coefficient of performance (COP) is used to estimate the performance index and efficiency of the AHP system. The average COP calculated in this study was 3.89 for a duration of 19-weeks. Similar to our findings, Jeong et al. [11] reported that the electricity consumption was significantly decreased in the AHP connected pig house due to the high $\mathrm{COP}$ value. A better COP value might help the AHP system to distribute uniform cool air inside the pig house. 


\section{Conclusions}

1. The implementation of the AHP cooling system could enhance the housing environment without adverse effects on the pig production traits.

2. The AHP cooling system resulted in a lower concentration of $\mathrm{NH}_{3}$ inside the pig house.

3. Despite the high installation cost, the government should provide subsidies to commercial swine farmers for sustainable pig production and environmental protection.

4. The AHP system can easily be installed, and its service lifetime lasts for more than 20 years with little maintenance.

5. Considering cooling effects and energy savings, the AHP system can be implemented in commercial swine farms as an innovative, eco-friendly and greener energy source.

Author Contributions: Conceptualization, H.-S.M., S.-R.L., K.-W.P. and C.-J.Y.; methodology, M.A.D., K.-W.P., D.R., H.-S.M. and S.-R.L.; validation, M.A.D., H.-S.M., I.-B.C. and C.-J.Y.; software, M.A.D. and H.-S.M.; formal analysis, H.-S.M., D.R., M.A.D., S.-R.L. and K.-W.P.; investigation, M.A.D., H.-S.M., D.R., S.-R.L. and K.-W.P.; data curation, H.-S.M., M.A.D. and D.R.; resources, S.-R.L., K.-W.P. and C.-J.Y.; writing —original draft preparation, D.R. and M.A.D.; writing—editing and review, M.A.D., H.-S.M., I.-B.C. and C.-J.Y.; visualization, M.A.D., H.-S.M. and D.R.; supervision, C.-J.Y., H.-S.M., I.-B.C. and K.-W.P.; funding acquisition, C.-J.Y. and K.-W.P.; project administration, K.-W.P. and C.-J.Y. All authors have read and agreed to the published version of the manuscript.

Funding: Korea's Ministry of Trade, Industry, and Energy financed this research.

Institutional Review Board Statement: The methodology was reviewed and approved by the IACUC (Institutional Animal Care \& Use Committee) at Sunchon National University (SCNU IACUC2020-09).

Informed Consent Statement: Not applicable.

Data Availability Statement: Not applicable.

Acknowledgments: The Industrial Technology Innovation Business (20194210100020, Development and Demonstration of Renewable Energy Mixed-Use System for the Livestock Industry) supported this research.

Conflicts of Interest: The authors have no conflict of interest.

\section{Nomenclature}

$\begin{array}{ll}\text { AHP } & \text { Air heat pump } \\ \text { THI } & \text { Temperature-humidity index } \\ \mathrm{CO}_{2} & \text { Carbon dioxide } \\ \mathrm{NH}_{3} & \text { Ammonia } \\ \mathrm{H}_{2} \mathrm{~S} & \text { Hydrogen sulfide } \\ \text { IACUC } & \text { Institutional Animal Care \& Use Committee } \\ \mathrm{CFM} & \text { Cubic feet per minute } \\ \mathrm{kWh} & \text { kilowatt hour } \\ \mathrm{kW} & \text { kilowatt } \\ \mathrm{COP} & \text { Coefficient of performance } \\ \mathrm{PM} \\ 2.5 & \text { Particulate matter } \\ \text { TVOCs } & \text { Total volatile organic compounds } \\ \text { SAS } & \text { Statistical analysis system } \\ \text { SEM } & \text { Standard error of the mean } \\ \text { BWG } & \text { Body weight gain } \\ \text { FI } & \text { Feed intake } \\ \text { FCR } & \text { Feed conversion ratio } \\ \text { CIGR } & \text { International Commission of Agricultural and Bio-Systems Engineering }\end{array}$




\section{References}

1. Corrée, W.J.; Jaap, J.S.; Verhagen, A. Energy Use in Conventional and Organic Farming Systems. In Proceedings of the Open Meeting of the International Fertiliser Society, London, UK, 17 April 2003.

2. Apak, R. Alternative Solution to Global Warming Arising from $\mathrm{CO}_{2}$ Emissions-Partial Neutralization of Tropospheric $\mathrm{H}_{2} \mathrm{CO}_{3}$ with $\mathrm{NH}_{3}$. Environ. Prog. 2007, 26, 355-359. [CrossRef]

3. Olivier, J.G.J.; Janssens-Maenhout, G.; Peters, J. Trends in Global CO 2 Emissions: 2012 Report; EUR 25388 EN; PBL Netherlands Environmental Assessment Agency, Publications Office of the European Union: The Hague, The Netherlands, $2012 ;$ p. 40.

4. Renaudeau, D.; Gourdine, J.L.; St-Pierre, N.R. A Meta-Analysis of the Effects of High Ambient Temperature on Growth Performance of Growing-Finishing Pigs. J. Anim. Sci. 2011, 89, 2220-2230. [CrossRef] [PubMed]

5. Mayorga, E.J.; Renaudeau, D.; Ramirez, B.C.; Ross, J.W.; Baumgard, L.H. Heat Stress Adaptations in Pigs. Anim. Front. 2019, 9 , 54-61. [CrossRef] [PubMed]

6. Jacobson, L.D.; Schmidt, D.R.; Lazarus, W.F.; Koehler, R. Reducing the Environmental Footprint of Pig Finishing Barns. Misc. Publ. 2011, 122609. [CrossRef]

7. Chmielowiec-Korzeniowska, A. The Concentration of Volatile Organic Compounds (VOCS) in Pig Farm Air. Ann. Agric. Environ. Med. 2009, 16, 249-256.

8. Lee, J.-Y. Current Status of Ground Source Heat Pumps in Korea. Renew. Sust. Energ. Rev. 2009, 13, 1560-1568. [CrossRef]

9. Wu, R. Energy Efficiency Technologies-Air Source Heat Pump vs. Ground Source Heat Pump. J. Sustain. Dev. 2009, 2, 14. [CrossRef]

10. Zhao, X.; Long, E.; Zhang, Y.; Liu, Q.; Jin, Z.; Liang, F. Experimental Study on Heating Performance of Air-Source Heat Pump with Water Tank for Thermal Energy Storage. Procedia Eng. 2017, 205, 2055-2062. [CrossRef]

11. Godyń, D.; Herbut, P.; Angrecka, S.; Corrêa Vieira, F.M. Use of Different Cooling Methods in Pig Facilities to Alleviate the Effects of Heat Stress-A Review. Animals 2020, 10, 1459. [CrossRef] [PubMed]

12. Xu, G.; Zhang, X.; Deng, S. A Simulation Study on the Operating Performance of a Solar-Air Source Heat Pump Water Heater. Appl. Therm. Eng. 2006, 26, 1257-1265. [CrossRef]

13. Jeong, M.G.; Rathnayake, D.; Mun, H.S.; Dilawar, M.A.; Park, K.W.; Lee, S.R.; Yang, C.J. Effect of a Sustainable Air Heat Pump System on Energy Efficiency, Housing Environment, and Productivity Traits in a Pig Farm. Sustainability 2020, 12, 9772. [CrossRef]

14. Mun, H.S.; Dilawar, M.A.; Jeong, M.G.; Rathnayake, D.; Won, J.S.; Park, K.W.; Lee, S.R.; Ryu, S.B.; Yang, C.J. Effect of a Heating System Using a Ground Source Geothermal Heat Pump on Production Performance, Energy-Saving and Housing Environment of Pigs. Animals 2020, 10, 2075. [CrossRef] [PubMed]

15. Islam, M.M.; Mun, H.-S.; Bostami, A.B.M.R.; Ahmed, S.T.; Park, K.-J.; Yang, C.-J. Evaluation of a Ground Source Geothermal Heat Pump to Save Energy and Reduce $\mathrm{CO}_{2}$ and Noxious Gas Emissions in a Pig House. Energy Build. 2016, 111, 446-454. [CrossRef]

16. Adebiyi, O.A.; Muibi, M.A.; Alaba, O. Performance and Behavioural Characteristics of Pigs as Affected by Types and Duration of Evaporative Cooling. Niger. J. Anim. Sci. 2017, 2, 103-113.

17. Wegner, K.; Lambertz, C.; Daş, G.; Reiner, G.; Gauly, M. Climatic Effects on Sow Fertility and Piglet Survival under Influence of a Moderate Climate. Animal 2014, 8, 1526-1533. [CrossRef] [PubMed]

18. Licharz, H.; Rösmann, P.; Krommweh, M.S.; Mostafa, E.; Büscher, W. Energy Efficiency of a Heat Pump System: Case Study in Two Pig Houses. Energies 2020, 13, 662. [CrossRef]

19. Myer, R.; Bucklin, R. Influence of Hot-Humid Environment on Growth Performance and Reproduction of Swine; Document AN107; Institute of Food and Agricultural Sciences, University of Florida: Gainesville, FL, USA, 2001. Available online: http://edis.ifas. ufl.edu/an107 (accessed on 3 October 2018).

20. National Oceanic and Atmospheric Administration (NOAA). Livestock Hot Weather Stress; Operations Manual Letter C-31-76; Department of Commerce, NOAA, National Weather Service Central Region: Kansas City, MO, USA, 1976.

21. Riva, G.; Pedretti, E.F.; Fabbri, C. Utilization of a heat pump in pig breeding for energy saving and climate and ammonia control. J. Agric. Eng. Res. 2000, 77, 449-455. [CrossRef]

22. Nienaber, J.A.; Brown Brandl, T.M. Heat Stress Effects on Growing-Finishing Swine. In Proceedings of the 25th Annual Carolina Swine Nutrition Conference, Raleigh, NC, USA, 10 November 2009; pp. 25-35.

23. Hessel, E.F.; Zurhake, C. Heating and Cooling Performance of an Under Floor Earth Tube Air Tempering System in a Mechanical Ventilated Farrowing House. In Proceedings of the XVII World Congress of the International Commission of Agricultural and Bio-Systems Engineering (CIGR), Québec City, QC, Canada, 13-17 June 2010.

24. Søren, P.; Krister, S. International Commission of Agricultural and Biosystems Engineering, 4th ed.; Research Centre Bygholm, Danish Institute of Agricultural Sciences: Horsens, Denmark, 2002; pp. 75-92.

25. Ni, J.-Q.; Heber, A.J.; Lim, T.-T. Ammonia and hydrogen sulfide in swine production. In Air Quality and Livestock Farming; CRC Press: Boca Raton, FL, USA, 2017; ISBN 978-1-315-73833-8.

26. Redwine, J.; Lacey, R.; Mukhtar, S.; Carey, J. Concentration and Emissions of Ammonia and Particulate Matter in Tunnel Ventilated Broiler Houses under Summer Conditions in Texas. Trans. ASAE 2002, 45, 1101-1109. [CrossRef]

27. Liang, Y.; Xin, H.; Tanaka, A.; Lee, S.; Li, H.; Wheeler, E.; Gates, R. Ammonia Emissions from U.S Poultry Houses: Part II-Layer Houses. In Proceedings of the 3rd International Conference on Air Pollution from Agricultural Operations, Research Triangle Park, Raleigh, NC, USA, 12-15 October 2003.

28. Rabczak, S.; Proszak-Miąsik, D. The Impact of Selected Heat Pumps on $\mathrm{CO}_{2}$ Emissions. E3S Web Conf. 2018, 45, 71. [CrossRef] 
29. Johansson, D. The Life Cycle Costs of Indoor Climate Systems in Dwellings and Offices Taking into Account System Choice, Airflow Rate, Health and Productivity. Build. Environ. 2009, 44, 368-376. [CrossRef]

30. Patteeuw, D.; Reynders, G.; Bruninx, K.; Protopapadaki, C.; Delarue, E.; D’haeseleer, W.; Saelens, D.; Helsen, L. CO 2 -Abate ment Cost of Residential Heat Pumps with Active Demand Response: Demand- and Supply-Side Effects. Appl. Energy 2015, 156, 490-501. [CrossRef] 